\title{
PREZENTACJE
}

\section{Jubileusz Księdza Profesora Ludwika Piechnika}

W 1995 roku obchodzilissmy 75 rocznice urodzin wybitnego historyka wychowania Księdza Profesora Ludwika Piechnika. Jest to postać szczególnie bliska wszystkim zajmującym się dziejami wychowania okresu staropolskiego.

Ksiądz Ludwik Piechnik urodzil się 9 VIII 1920 w Krzesławicach koło Myślenic. W 1938 wstapił do zakonu jezuitów. Studiował filozofię i teologie oraz pedagogikę na Wydziale Filozoficzno-Historycznym Uniwersytetu Jagiellońskiego w latach 1949-1952. Doktorat uzyskał 16 III 1962 roku na podstawie pracy „Początki Akademii Wileńskiej” (promotor Jan Hulewicz). W 1990 roku uzyskał tytuł profesora zwyczajnego. Prefekt kleryków w Krakowie w latach 1957-64, profesor pedagogiki na Wydziale Filozoficznym Towarzystwa Jezusowego i na $\mathrm{Pa}$ pieskiej Akademii Teologicznej w Krakowie. W latach 1966-72 dyrektor Wydawnictwa Apostolstwa Modlitwy w Krakowie. Superior w Krakowie (Przegorzały) 1971-84 i Domu Kuznowicza od 1992. Jest autorem wielu rozpraw naukowych, głównie z zakresu historii szkolnictwa jezuickiego, w tym czterotomowych „Dziejów Akademii Wileńskiej” (1983 - 1990).

Spragniony gruntownej wiedzy o dokonaniach Towarzystwa Jezusowego w Polsce w dziedzinie naukowo-wychowawczej, znajdzie ją w dorobku pisarskim o. Ludwika Piechnika. Monumentalna, 1144 stronicowa monografia: „Dzieje Akademii Wileńskiej” oraz 26 pomniej- szych prac, o łącznej objętości 767 stronic druku, rozrzuconych w wielu czasopismach ${ }^{1}$ oraz w wydawnictwach zbiorowych ${ }^{2}$ dają całokształt dziejów nauczania jezuickiego w Rzeczypospolitej Obojga Narodów. Przerażony ogromem czekającej go lektury, po przeczytaniu Piechnikowych opracowań, przekona się, że warto było brać do ręki poszczególne woluminy, kryjące, pod postacią zadrukowanych stron, prawdę o wielkich dziełach Bożych, które zrodziły się ze zrozumienia czym jest służba Chrystusowi w Ludzie Bożym pod sztandarem Krzyża i przewodnictwem papieża

Dorobek naukowy Piechnika oparty jest na nieopublikowanych, rękopiśmiennych materiałach archiwalnych. Sq to zawsze nowatorskie opracowania tematów, których daremnie szukać w innej literaturze. Dla poparcia wlasnego osadu cytuję poniżej dwie wypowiedzi na temat dzieła o. Piechnika o Akademii Wileńskiej.

Roman Plefkaitis, Litwin, profesor Uniwersytetu Wileńskiego napisal: „Wnikliwie studiowałem rozprawe ks. Piechnika i wyciaggnąłem $\mathrm{z}$ niej oczywisty wniosek: $w$ tym studium jest to, co mi potrzebne dla własnych badań, a wcześniejsze prace historyków nad początkami Uniwersytetu Wileńskiego są niedokladne i przygotowane powierzchownie [...]. Studium Piechnika jest przykładem, jak wiele może osiągnąć historyk oświaty mający dobre przygotowanie do badań [...]. Praca Piechnika jest oparta na solidnym fundamencie empirycznym"

\footnotetext{
I "Nagza Przeszlośc”, „Studia Warmińskie”, „Studia Theologica Varsoviensia”, „Collectanea Theologica”, "Rocrniki Humanistyczne", "Analecta Cracoviensia”, „Studia Teologiczme”, „Horyzonty Wiary", „Kalendarz Serca Jezusowego", „Rocznik Wydziału Filozolicznego Tow arzystwa Jezusowego w Krakowie".

d Dzieje teologii katolickiej w Polsce (Lublin 1975), Studia z dziejów obwiaty $i$ kultury umyslowej w Polsce XVII $i$ XIX w. (Wroctaw 1977), Dzieje Lubelszczyzny (1989), Jezuici, a kultura polsko (1993)

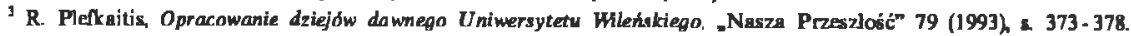


I wtóre świadectwo, tym razem historyka polskiego: „Praca prof. L. Piechnika, w wielu wypadkach odkrywcza i posuwająca naprzód badania nad szkolnictwem jezuickim i nad Akademį̨ Wileńską w szczególności, stanie się zapewne również cennym punktem wyjścia dla innych badaczy, pragnących zając się historią wychowania w Polsce i na Litwie [-]. Dzieło Piechnika daje świadectwo ogromnego wkładu jezuitów do kultury umyslowej Rzeczypospolitej Obojga Narodów [...]. Dzielo zmusza do realizacji wielu obiegowych poglądów na temat roli jezuitów w dziejach naszej kultury"4.

Stanislaw Obirek SI

4 J. Wos', Pagadanki historyczne, Kraków 1991, a 126: 123-126.

\section{Bibliografia prac Ks. Prof. Ludwika Piechnika SJ}

\section{8}

1. Gimnazjum w Braniewie $\boldsymbol{w} \boldsymbol{X V}$ w. Studium o poczqtkach szkolnictwa jezuickiego w Polsce, Nasza Przeszlość 7 (1958), s. 5-72.

\section{9}

2. Poczqtki seminariów nauczycielskich w Polsce w wieku XV, Nasza Przeszloscc, 10 (1959), s. $159-175$.

\section{4}

3. Jezuici a seminarium diecezjalne w Kaliszu (1593-1620), Nasza Przeszlośc, 20 (1964) s. $113-147$.

\section{8}

4. Starania biskupów warminiskich $i$ jezuitów polskich o przeksztalcenie kolegium w Braniewie na uniwersytet, Studia Warmińskie, 5 (1968), s. $67-76$.

5. Konkwit szlachecki w Braniewie (15651600), Studia Warmińskie, 5 (1968), s. 89 -98.

1969

6. Dzialalnosé jezuitów na polu szkolnictwa w Poznaniu, Nasza Przeszłość, 30 (1969), s. $171-210$.

\section{0}

7. Seminarium diecezjalne $w$ Sandomierzu (1635-1773), Studia Theologica Varsoviensia, $8(1970)$, s. $159-229$.

1971

8. Jezuickie Collegium Nobilium w Warszawie (1752 - 1777), Nasza Przeszłość, 35 (1971) s. $115-152$
9. Studium matematyczne i projekt Akademii Wojskowej Bartlomieja Wasowskiego, Nasza Przeszłość, 36 (1971), s. 175 - 187.

\section{3}

10. Accademia Romana, w: Encyklopedia katolicka, t. 1, Lublin 1973, kol. 51.

11. Accademia degli Arcadi. Tamże, kol. 51 52.

12. Accademia di Santa Cecilia. Tamże, kol. 52

13. Dochtorowicz Fabian SJ, w: Encyklopedia katolicka, t. 4, Lublin 1973, kol. 1-2.

14. Poczatki Akademii Wileńskiej (1569. 1600), Nasza Przeszlość, 40 (1973), s. 5- 173.

\section{5}

15. Akademie i uczelnie jezuickie, w: Dzieje teologii katolickiej w Polsce, t. 2, cz. 2, Lublin 1975 , s. $51-101$.

\section{6}

16. Nowe elementy wniesione przez jezuitów do szkolnictwa polskiego w XV wieku, Collectanea Theologica, 1 (1976), s. 67-7.

17. Jezuickie seminaria diecezjalne w Polsce (1564-1773), Collectanea Theologica, 46 (1976), s. $45-69$.

18. Encyklopedia katolicka, t. 2, Lublin 1976. Hasło: Celtes Konrad, kol. 1416.

\section{7}

19. Rzut oka na powstanie, rozwój i likwidacje jezuickiego Collegium Nobilium w Wilnie, w: Studia $z$ dziejów oswiaty $i$ kultury umyslowej w Polsce XVII i XIX w. Ksiega Ofiarowane Janowi Hulewiczowi, Wrocław 1977, s. 81-96. 
20. Przemiany w szkolnictwie jezuickim w Polsce XVII wieku, Roczniki Humanistyczne, 2 (1977), s. 31-61.

1978

21. Olizarowski Aron Aleksander, w: Polski Slownik Biograficzny, 23 (1978), s. 822-823.

1979

22. Olszewski Jakub, w: Polski Słownik Biograficzny, 24 (1979), s. 21-22.

23. Encyklopedia katolicka, t. 3, Lublin 1979. Hasło: Chevalier Jan, kol. 144.

1981

24. Slownik polskich teologów katolickich. Pod red. H. E. Wyczawskiego, t. 1, Warszawa 1981. Hasła: Chadzyñski Jan, s. 280 - 281; Elger Jerzy, s. 443-444; Faunt Artur Wawrzyniec, s. 455-457; Ginkiewicz Michal, s. 526-527; Grużewski Jan, s. 583 - 584 .

\section{2}

25. Slownik polskich teologów katolickich. Pod red. H. E. Wyczawskiego, t. 2, Warszawa 1982. Hasła: Klinger Piotr, s. 288; Kojalowicz Wjuk Kazimierz, s. 317-318; Lauksmin Zygmunt, s. $498-500$.

26. Slownik polskich teologów katolickich. Pod red. H. E. Wyczewskiego, t. 3, Warszawa 1982 Hasła: Ortiz Jakub, s. 264-265; Rabb Justus, s. 472 - 473; Radzimiński Adrian, s. 482 483; Rostoga Tomasz, s. 508; Roth Michal, s. 511; Rywocki Jan, s. 543-545.

27. Zakony $w$ archidiecezji krakowskiej za rzqdów Adama Stefana Sapiechy, w: Ksiega Sapieżyńska, t. 1, Kraków 1982, s. 339 - 368.

\section{3}

28. Rozkwit Akademii Wleńskiej w latach 1600-1655, Rzym 1983, s. 313. Dzieje Akademii Wileńskiej, t. 2.

29. Slownik polskich teologów katolickich. Pod red. H. E. Wyczewskiego, t. 4, Warszawa 1983. Hasła: Schönhoff Grzegorz, s. 29; Sokulski Stanislaw, s. 137-138; Soxo de Benedykt, s. 160-161; Stefanowski Hieronim, s. 206 - 207; Szafarzyński Jakub, s. 244-245; Szrubowski Franciszek, s. 284-285; Szyrwid Konstanty, s. 294 -295; Smiglecki Marcin, s. 306 -309; Tobolski Wojciech, s. 330-331; Tolgsdorf Erdmann, s.
331 -332; Toloczko Józef, s. 332; Tylkowski Wojciech, s. 425-426: Zahuski Eukasz, s. 525 - 526.

1984

30. Poczqtki Akademii Wileńskiej (15691599), Rzym 1984, s. 263 (Dzieje Akademii Wileñskiej, t. 1).

31. Seminarium diecezjalne w Poznaniu w latach 1564 - 1614, Nasza Przeszłość, 61 (1984), s. 93- 109 .

$$
1987-1988
$$

32. Próby odnowy Akademii Wileńskiej po kleskach potopu $i$ okres kryzysu 1655-1730, Rzym 1987, s. 261 (Dzieje Akademii Wileńskiej, t. 3).

33. Związki kulturalne dawnej Akademii Wileńskiej z Zachodem w latach 1570 - 1773, Analecta Cracoviensia, 19 (1987), s. 343-362.

34. Seminaria duchowne $w$ (archi)diecezji wileńskiej do 1939 r., Studia Teologiczne, Białystok, Drohiczyn, Lomża, 5 - 6 (1987-1988), s. $201-231$.

1989

35. L'attività di Lorenzo Maggio nell'ambito dell'istruzione pubblica in Polonia, w: Studi offerti a Jan Władysław Woś, Firenze 1989 , s. 45.

36. Dzialalnosć kulturalna Towarzystwa Jezusowego na pótnocnych $i$ wschodnich ziemiach Polski w ХVI-XVII wieku, Dzieje Lubelszczyzny, 6 (1989), s. 75-96.

37. Franciszek Ksawery św., w: Encyklopedia katolicka, t. 5, Lublin 1989, kol. 453-454.

38. Gabrielli Giovanni Maria OCR. Tamze, kol. 796. 39. Garet Jean CRSA. Tamże, kol. 868-869. 40. Gener Juan Bautista SJ. Tamże, kol. 943.

\section{0}

41. Odrodzenie Akademii Wileńskiej 17301773, Rzym 1990, s. 307 (Dzieje Akademii Wileńskiej, t. 4).

42. Szkoly jezuickie w Polsce w latach $1564-1773$, Horyzonty Wiary, 3 (1990), s. $69-80$.

$$
1991-1992
$$

43. Trójglos o jezuickim wychowaniu, Kalendarz Serca Jezusowego, (1991), s. 88-97. 
44. Podstawy pedagogiki chrześcijańskiej, Rocznik Wydziału Filozoficznego Towarzystwa Jezusowego w Krakowie 1991-1992, s 72 - 74.

45. Wyklady Jana Kormana na Katedrze Polityki Uniwersytetu Wileńskiego, Rocznik Wydziału Filozoficznego Towarzystwa Jezusowego w Krakowie 1991-1992, s. 267-275.
1993

46. Dzialalnośc jezuitów polskich na polu szkolnictwa (1565 - 1773), w: Jezuici a kultura polska, Kraków 1993, s. 243-259.

47. Zapis wykladów na katedrze polityki profesora Akademii Wileńskiej Jana Kormana, Horyzonty Wiary, 16 (1993), s. 70-77.

\section{Historia wychowania w Wyższej Szkole Pedagogicznej w Rzeszowie}

W bieżącym roku mija 12 lat od utworzenia Zakładu Historii Oświaty i Wychowania w Wyższej Szkole Pedagogicznej w Rzeszowie. Jednak początek działalności naukowej i dydaktycznej z zakresu historii wychowania jest związany z powstaniem Zakładu Andragogiki i Historii Wychowania (1981 r.) wchodzącego w skład Instytutu Pedagogiki i Psychologii, a od 1986 roku Instytutu Pedagogiki. Kierownikiem Zakładu był dr Andrzej Janczur. Wcześniej przedmiot ten był realizowany przez pracowników Katedry Pedagogiki, natomiast w zakresie badań naukowych dominowały prace indywidualne związane glównie $z$ uzyskaniem stopni naukowych. Dalsze zmiany organizacyjne, tj. powołanie Zakładu Historii Oświaty i Wychowania (1984 r.) przyczyniły się do rozwinięcia planowej działalności naukowej w tym zakresie. Kierownictwo Zakładu powierzono doc. dr hab. Andrzejowi Meissnerowi.

W ciagu 12 lat funkcjonowania Zakładu zespół historyków wychowania powiększał się, a jego pracownicy zdobywali stopni naukowe. Obecnie Zakład liczy 8 pracowników: 2 profesorów (A. Meissner, Czesław Majorek), 5 doktorów (Adam Horbowski, Czesław Płaza, Jerzy Potoczny, Kazimierz Szmyd i Władysława Szulakiewicz) oraz 1 magistra (Adam Krzanowski).

Do najważniejszych przedsięwzięć naukowych zrealizowanych w tym okresie należy zaliczyć organizację konferencji naukowych. Pierwsza z nich nt „Stan i potrzeby badań nad dziejami oświaty w Galicji" odbyła się w 1986 r. W 1989 r. ukazały się materiały pokonferencyjne pt. „Z dziejów oświaty w Galicji” pod red. A. Meissnera. Pracownicy Zakładu uczestniczyli także w międzynarodowej konferencji zorganizowanej w WSP w Rzeszowie nt „Galicja $\mathrm{i}$ jej dziedzictwo” (1992 r.), z której materiały zostały opublikowane w 3 tomie serii wydawniczej „Galicja i jej dziedzictwo" (zatytułowanym „Nauka i oświata”, Rzeszów 1995). Kolejną inicjatywą naukową była międzynarodowa sesja poświęcona „Myśli edukacyjnej w Galicji” (1995 r.). Również dorobek tej ostatniej zostanie wydany w odrębnym tomie pod redakcja A. Meissnera i Cz. Majorka.

Działalność badawcza pracowników Zakładu obejmuje dzieje oświaty i myśli pedagogicznej XIX i XX wieku. W obrębie jednak tak szeroko pojętej problematyki można wyodrębnić kilka szczegółowych zagadnień, będących przedmiotem zainteresowań poszczególnych badaczy. M.in. beda to:

- dzieje oświaty i myśli pedagogicznej w Galicji, nad którymi pracują A. Meissner, J. Potoczny, W. Szulakiewicz;

- historia oświaty dorosłych, która zajmują się A. Horbowski i J. Potoczny;

- dzieje organizacji oświatowych pozostajace w kręgu zainteresowań Cz. Płazy i A. Krzanowskiego;

- historia myśli pedagogicznej w II Rzeczypospolitej, nad którą skupiają się K. Szmyd i W. Szulakiewicz;

- oświata i szkolnictwo po II wojnie światowej, którq̨ badaja A. Meissner i A. Horbowski.

Dorobek naukowy w obrębie wymienionej problematyki badawczej jest znaczny i nie sposób go przedstawić w niniejszej publikacji. Warto jednak podkreślić, iż obecnie można 